\title{
Deep-sea environment and biodiversity of the West African Equatorial margin
}

\author{
Myriam Sibuet $^{\mathrm{a}, \mathrm{b},{ }^{*}}$ and Annick Vangriesheim ${ }^{\mathrm{a}}$ \\ a Ifremer, Département DEEP/LEP, Centre de Brest, BP70, 29280 Plouzané, France \\ b Institut Océanographique, 195 rue Saint-Jacques, 75005 Paris, France \\ *: Corresponding author : M. Sibuet, email address : myriam.sibuet@wanadoo.fr
}

\begin{abstract}
:
The long-term BIOZAIRE multidisciplinary deep-sea environmental program on the West Equatorial African margin organized in partnership between Ifremer and TOTAL aimed at characterizing the benthic community structure in relation with physical and chemical processes in a region of oil and gas interest. The morphology of the deep Congo submarine channel and the sedimentological structures of the deep-sea fan were established during the geological ZAIANGO project and helped to select study sites ranging from 350 to $4800 \mathrm{~m}$ water depth inside or near the channel and away from its influence. Ifremer conducted eight deep-sea cruises on board research vessels between 2000 and 2005. Standardized methods of sampling together with new technologies such as the ROV Victor 6000 and its associated instrumentation were used to investigate this poorly known continental margin. In addition to the study of sedimentary environments more or less influenced by turbidity events, the discovery of one of the largest cold seeps near the Congo channel and deep coral reefs extends our knowledge of the different habitats of this margin. This paper presents the background, objectives and major results of the BIOZAIRE Program. It highlights the work achieved in the 16 papers in this special issue. This synthesis paper describes the knowledge acquired at a regional and local scale of the Equatorial East Atlantic margin, and tackles new interdisciplinary questions to be answered in the various domains of physics, chemistry, taxonomy and ecology to better understand the deep-sea environment in the Gulf of Guinea.
\end{abstract}

Keywords: Gulf of Guinea; Congo canyon; Turbidity current; Benthos diversity; Cold-seep communities; Cold coral 


\section{Introduction}

The idea of the Biozaire deep sea project in the West Equatorial African margin off Gabon, Congo and Angola emerged in 1998 when industrial (Total) and scientific interest arrived at a mature stage for mutual benefits. The deep-sea biodiversity of the Atlantic continental margin off Angola, Congo and Gabon was mostly unknown before petroleum exploration. The most extended ecosystem in the deep ocean is based on the input of detritus and organic carbon produced photosynthetically in the euphotic upper layer of the ocean. The majorities of the benthic communities survive with low food resource, low temperature and are characterized by low faunal densities, high species richness and small body size (Grassle and Maciolek, 1992). On continental margins high gradients of extreme conditions, various sources of energetic input and contrasting habitats drive the slope communities. On both active and passive margins, highly productive ecosystems can take place on localized areas such as deep coral reefs, cold seeps, particularly methane seeps which enable an autochthonous, chemosynthetic primary production (Sibuet and Olu-Le Roy, 2002; Sibuet and Olu, 1998). Very few biological and no ecological studies had been reported in the literature in the eastern part of the deep Atlantic at low latitudes. Ifremer and Total initiated in 1998 a multidisciplinary program with the general aim to understand the structure and the functioning of deep-sea ecosystems in this region. The geological context acquired during the Zaiango project in the Gulf of Guinea (Savoye et al., this volume) was essential to recognize major geological features influencing deep sea habitats and in consequence to select study areas for observation, sampling and experimentations during the Biozaire project. The main feature of the continental margin in the Gulf of Guinea is the Congo (exZaire) deep-sea fan composed of a submarine canyon connected to the Congo River followed by a deep-sea channel (Babonneau et al., 2002). The Congo River, the second most voluminous river in the world after the Amazon River, supplies a large volume of particulate and dissolved organic matter to the ocean, both at the surface and at the seabottom through the turbidity activity in the Congo canyon. This canyon cuts deeply into the shelf and the continental slope and feeds a $1250 \mathrm{~km}$ long meandering valley where the sediment input is transported by episodic turbidity currents. Anomalies in the deep water layer have been previously observed (Arhan et al., 1998; Van Bennekom, 1996; Van Bennekom and Berger, 1984; Warren and Speer, 1991). They consist in an oxygen deficit and a nutrient excess on the sediment interface at $\sim 4000 \mathrm{~m}$. It was attributed to the mineralization of the particulate organic matter provided by the Congo River. It seemed necessary to study in detail this strange deep feature and try to evaluate its influence on the benthic fauna at these depths.

Prior to these studies of this passive margin, the existence of chemosynthetic based communities was assumed only by sporadic citations of one Vesicomyid species taken by the R/V Valdivia in 1898, Calyptogena valdiviae (Thiele and Jaeckel, 1931) in the Gulf of Guinea. A piece of coral was caught by an industrial ROV offshore Angola during industrial exploration, which suggested the existence of typical features or mounds created by cold coral reefs.

The concerted action between Ifremer and Total lead to the initiation of an exploratory program combining a series of geological cruises introducing a minimum of biological operations followed by ecological cruises driven by the originality and complexity of that region with many types of habitat. Following the geological project Zaiango, the Biozaire project (2000 to 2005) was initiated and organized by the Deep-Sea Environment Department at Ifremer.

The long-term Biozaire multidisciplinary deep-sea environmental program on the West Equatorial African margin aimed to study selected sites in areas under the influence of cold seeps and of the input of the Congo River compared with areas assumed not to be under these influences. The sampling strategy benefited from the experience gained during previous deep-sea ecology studies (Rabouille et al., 1993; Sibuet et al., 1993) but was adapted to include ROV Victor 6000 dives for the first time. 
The very early data obtained during the first oceanographic cruises of the program, brought original results from the investigation near exploration well sites on block 17 and on particular habitats discovered using the ROV Victor 6000 (Sibuet et al., 2002). We explain in this paper the background and objectives of the Biozaire program linked in 2005 to the Census of Marine Life program through the COMARGE, ChEss and CeDAMar projects. It highlights the major results presented in the collection of 17 papers, which present detailed scientific results, and raises new questions in the various domains of physics, chemistry, taxonomy and ecology that are necessary to obtain a comprehensive understanding of the Gabon, Congo and Angola margin environment.

\section{Objectives}

With the expansion of deep offshore oil and gas industry, there was a need for baseline studies to assess possible ecological impacts. The Biozaire program developed regional and local surveys to identify and analyze environmental variables, benthic processes, and the scales of variability of benthic communities necessary to predict their response to deep-sea industrial activities.

With its multiple objectives the Biozaire program aimed to gain at a better understanding of the regional and local variables, along with the influence of habitats and different sources of energy on the structure of the communities (fig. 1). The objectives were:

To determine the influence of the Congo River discharge, both in the surface layer and in the near-bottom layers; particularly, to explain the presence and extent of deep anomalies in oxygen (deficit) and nutrient (excess) concentrations near $4000 \mathrm{~m}$ depth already revealed by previous studies near the Congo channel;

To monitor the deep layer currents at a regional scale during the duration of the project with a specific focus on turbidity currents in the Congo submarine channel;

To evaluate the trophic resources by measuring the organic carbon flux and its temporal variability as well as the mineralization processes on selected sites;

To identify the benthic fauna and define the species composition and the diversity of the different size categories at the same sites: the megafauna, the macrofauna and the meiofauna;

To determine the abundance and the biomass of the different faunal components;

To evaluate the spatial variability of the biological compounds together with the physical and chemical characteristics at the water-sediment interface;

To undertake and compare long term in situ colonization experiments at bathyal $(1300 \mathrm{~m}$ depth) and abyssal depths (4000 m depth);

To characterize the bacterial activity in relation with hydrocarbon and methane seeps;

To locate and identify chemosynthetic based communities, symbiotic associations and the accompanying fauna in relation with local environmental variables (i.e. methane concentrations);

To identify coral mounds fauna and explain their presence.

\section{General strategy of the program and definition of study sites}

During the Biozaire deep-sea environment program several study sites were selected for integrated studies from $350 \mathrm{~m}$ down to $4800 \mathrm{~m}$ depth near and far outside of the Congo channel, including Block 17 offshore Angola at $1300 \mathrm{~m}$ depth for preliminary samplings before the beginning of oil exploitation. The sites were chosen in order to study contrasted habitats on the base of topographic, sedimentological, and geophysical data obtained during the Zaiango geological program (Savoye et al., 2000) (Fig. 2 and Table 1). The geological context of the Biozaire sites is described in (Savoye et al., this volume). 
Five sites were sampled and surveyed with an integrated strategy describing physical chemical and biological characteristics :

- Site ZA : at 1300-1400m water depth offshore Angola, area of oil and gas prospection

- Site ZC: at $4000 \mathrm{~m}$ offshore Angola supposed to be out of any peculiar influence,

- Site ZD: at $3950 \mathrm{~m}$ water depth,13 km south of the Congo Channel,

- Site ZD': inside the Congo channel (the thalweg) at $4050 \mathrm{~m}$ depth

- Site Regab: at $3150 \mathrm{~m}$ depth, $8 \mathrm{~km}$ North of the Congo channel, a large pockmark area with active seeps discovered during the Zaiango-Rov cruise in 2000 ,

Six other sites were explored with less integrated strategy:

-Site ZR': inside the Congo channel at 3420 m depth near Site Regab,

- Site LOBE: in the distal portion of the Congo channel at $4800 \mathrm{~m}$ depth

- Site ZB: Coral mounds between 330m - 420 m water depth upper slope off Angola,

- Site Tête: inside the upper Congo canyon, at depths from 225 to 1594 m,

- Site Guiness: at 500 m depth offshore Gabon, an area of small pockmarks

- Site Diapir: at 2700m depth offshore Angola, a supposed cold seep area

Eight oceanographic cruises onboard Ifremer research vessels organized between 2000 and 2005, contributed to achieving the objectives of the Biozaire Programme (Table 2). The first operations began in March 2000 during a geological cruise called Zaïango Obs-Biol 1 organized onboard the R/V Le Suroît, during which long-term moorings were deployed (Fig. 3) for a 10-month period on the seafloor, at 3 sites (ZA at $1350 \mathrm{~m}$ depth, ZC and ZD at $4000 \mathrm{~m}$ depth). A second cruise called Zaïango-Biol 2 onboard the R/V Thalassa (designed for benthic trawling down to $2000 \mathrm{~m}$ depth) allowed sampling at two sites of Block 17 at $1350 \mathrm{~m}(\mathrm{ZA})$ and at $400 \mathrm{~m}$ depth (ZB) respectively, with a beam trawl, a USNEL box corer and a multiple corer (Fig. 3). The first ROV Victor 6000 dives during the Zaïango-Rov cruise in December 2000 enabled the exploration of pockmarks and the discovery of associated chemosynthetic based fauna. Two cruises Biozaire 1 and Biozaire 2 were undertaken on board R/V L' Atalante with the ROV VICTOR 6000 in order to achieve quantitative sampling of all faunal size categories and environmental factors. The Biozaire 3 cruise was undertaken on board R/V L'Atalante to complete the sampling and achieve an hydrological survey. In addition, two short cruises Biozrecup on the R/V Le Suroit and Biozrecup2 on the R/V Beautemps-Beaupré were devoted to the long-term mooring maintenance and recovery of moorings in 2005.

The sampling, mooring and ROV survey sites appear on the map of Figure 2, the CTD-O survey stations appear on the map of the Figure 3.

The types and numbers of surface operations are listed in Table 2. All the data and metadata are stored in Ifremer Biocean database (Fabri et al., 2006) and metadata are available on the web site http://www.ifremer.fr/biocean. Species level taxonomic identifications and metadata are available on the Ocean Biogeographic Information System portal (http://www.iobis.org) of the Census of Marine Life Programme (http://www.coml.org/) as well as on GBIF web portal (Global Biodiversity Information Facilities http:Ilwww.gbif.org).

\section{Strategy for physical and chemical sampling in deep water}

To study in detail the deep anomalies, a $\mathrm{CTD}-\mathrm{O}_{2}$ station grid was performed during the Biozaire3 cruise along the Congo channel and at $4000 \mathrm{~m}$ depth (Fig. 3). Water samples were taken to measure nutrients, stable isotopes of oxygen and carbon, dissolved inorganic carbon and $\mathrm{pH}$ (Vangriesheim et al., this volume-b). A benthic silicate mass balance was established (Ragueneau et al., this volume) as well as direct measurements of biogenic silica dissolution in the deep waters and in the sediments.

The variability of currents was established with long-term moorings installed from 2000 to 2005. Usually, the moorings were equipped with two sets of instruments, one near the seabottom and the other at shallower depth. Each set was composed of a current meter, a 
sediment trap and a turbiditmeter(Vangriesheim et al., this volume-a). The vertical fluxes of particulate matter were measured by using the sediment traps on the long-term moorings. Organic carbon fluxes were then calculated from particle analysis.

Accumulation rates were derived from sedimentation rates estimated by short-live radioisotopes $\left({ }^{210} \mathrm{~Pb}_{\mathrm{xs}}\right.$ and $\left.{ }^{228} \mathrm{Th}_{\mathrm{xs}}\right)$ and organic carbon content of the sediment. Organic carbon recycling was estimated using a new combination of in situ techniques on a single platform (benthic chambers, microprofiler) and onboard measurements of oxygen microprofiles (Rabouille et al., this volume) .In addition, sediment trap fluxes, sediment composition (Org-C, Tot- $\mathrm{N}, \mathrm{CaCO}_{3}$, porosity) and radionuclide profiles provided measurements of input fluxes and burial rate of organic and inorganic compounds.

\section{Strategy for ecological studies}

For each site in sedimented areas and in addition to long-term moorings deployed to measure organic carbon fluxes (Rabouille et al., this volume) and colonization rates with autonomous free vehicles (Menot et al., this volume), different sampling gear has been used to collect the sediment and all faunal size categories.

In order to obtain abundances of the different size categories and to assess the spatial variability within and between sites, the sorting and estimation of mean densities have been obtained by a minimum of three replicates using three different types of equipment.

The megafauna was collected using a beam trawl, which consists of a wooden beam (6-m long) attached to two iron shoes acting as a frame for the net. The mesh size decreased from 2 to $1 \mathrm{~cm}$ from the mouth to the end.

All specimens larger than $1 \mathrm{~cm}$ were sorted onboard to the level of the phylum, class, order, family, genus or species. They were counted and weighed. Some of them were dissected onboard for biological purpose, The others were preserved in $3 \%$ borax-buffered formaldehyde before their long-term conservation in alcohol.

The macrofauna was sampled using a USNEL spade boxcorer (total surface area of 0.25 $m^{2}$ ). Samples were processed immediately after recovery. Large megafaunal animals were removed before horizontal subdivisions of the core. The sediment collected was then divided into five horizontal layers before sieving processing from $1 \mathrm{~mm}$ to $250 \mu \mathrm{m}$ and preservation in $4 \%$ borax-buffered formaldehyde before their long-term conservation in alcohol

The meiofauna was sampled with a multiple corer equipped with. 12 tubes of $6-\mathrm{cm}$ inner diameter. The sediment was sub-sampled into five layers down to $5 \mathrm{~cm}$ depth. The subsamples obtained from each tube were preserved in $4 \%$ borax-buffered formaldehyde.

The ROV Victor allowed to undertake near sea-bottom surveys on mixed hard and sediment seafloor, which allows to discover particular habitats: hard concretions associated with fluid escape in pockmarks, and areas with small mounds created by cold coral growth. The video observations along regular ROV tracts permit to characterize the spatial distribution of biological and geological features. On stations selected for integrated studies, targeted samples of sediment and fluids have been taken with a tube core and with a fluid sampler device. The megafauna was collected with a claw fixed to the arm of the ROV, the macrofauna with a blade corer adapted from the first generation of blade corer (Cahet and Sibuet, 1986; Sibuet et al., 1990) and the meiofauna with a tube core.

\section{Highlight of results}

The Biozaire study areas are located inside and outside one of the main active deep-sea fans in the world ocean. The geological background is presented in this volume by Savoye et al. (this volume). The Congo submarine valley ends at the Lobe area, more than $750 \mathrm{~km}$ 
away from the coast in $~ 5000 \mathrm{~m}$ water depth. The activity of the Congo fan, which is unusual compared to other known deep-sea fans of the same size - Amazon, Nile, Mississippi are inactive to-day - is explained by the direct connection of the Congo estuary with the head of the Congo canyon.

\subsection{Dynamics, turbidity currents and deep-water column anomalies}

From the long-term moorings installed in the whole area (Vangriesheim et al., this volume-a) the regional dynamics is characterized by very weak currents affected by high temporal variability in three distinct time periods: semi-diurnal tidal oscillations, inertial oscillations (45 days) and 15-day oscillations. Biweekly oscillations discovered during Biozaire at site ZA have already been reported (Vangriesheim et al., 2005) and were attributed to coastaltrapped waves (CTW) by Guiavarc'h et al. (2007; 2008). The residual currents calculated for each of the deep sites outside the Congo channel were in agreement with the expected direction (east and/or south) of the deep-water flow in this area.

The long-term moorings installed in and around the Congo submarine channel documented two kinds of turbidity events: those associated with high current energy and high sediment transport and those without significant changes in current intensity (Vangriesheim et al., this volume-a). A strong event that occurred at $\sim 4000 \mathrm{~m}$ in 2001 was described by Khripounoff et al. (2003). The mooring surfaced when the bottom current speed exceeded $121 \mathrm{~cm} \mathrm{~s}^{-1}$. The sediments overflowed outside the channel up to site ZD, $13 \mathrm{~km}$ south of the channel. During 2003 and 2004, sediment flux peaks were also observed but without current speed change. They were probably due to local sliding of sediment accumulated on the walls or terraces on the side of the channel. In January 2004, a strong turbidity event was observed at all three moorings deployed along the channel at different depths (sites ZR', ZD' and site Lobe) (Vangriesheim et al., this volume-a) . It caused sudden jumps in current speed. Moorings were tilted and displaced at sites ZR' $(3420 \mathrm{~m})$ and ZD' $(4070 \mathrm{~m})$ and resulted in high sediment deposition at all the three mooring sites. The turbidity current displacement velocity was estimated to $3.5 \mathrm{~m} \mathrm{~s}^{-1}$ on average along the numerous channel meanders between $3420 \mathrm{~m}$ and $4070 \mathrm{~m}$, and then to $0.7 \mathrm{~m} \mathrm{~s}^{-1}$ between $4070 \mathrm{~m}$ and the end of the channel at $4790 \mathrm{~m}$.

These long-term moorings recorded unexpected events due to turbidity currents, showing that the Congo channel is a very active system with highly energetic turbidity currents causing rapid transport of large quantities of sediment over very long distances. The observations confirm hypotheses based on geological data that these flows with high concentrations of sediment rich in organic matter can only overflow the channel when the trough height is sufficiently small at water depths exceeding $4000 \mathrm{~m}$ depth.

For the deep-water layer, the CTD- $\mathrm{O}_{2}$ network allowed a more detailed description of the deep anomaly, with its oxygen decrease and nutrient increase (Vangriesheim et al., this volume-b).It appeared on the sea-bottom at $4000 \mathrm{~m}$ and became slightly shallower when it expanded to the West. It also expanded north and south on the sea-bottom along the 4000$\mathrm{m}$ isobath. DIC and $\delta^{13} \mathrm{C}$ measurements confirm the role of mineralization of organic matter in these anomalies.

From a benthic silicate balance established from this network sampling, Ragueneau et al. (this volume) demonstrate that the deep silicate anomaly originates from the sediments, thereby confirming the Van Bennekom et al. (1996) hypothesis of an upward diffusion of the silicate from the sediment. Such an anomalous phenomenon also seems to occur deeper in the Congo Lobe, where the Congo channel disappears, with weaker anomalies but with a significant $\mathrm{pH}$ decrease on the sea-bottom which was not seen at $4000 \mathrm{~m}$.

The area near $4000 \mathrm{~m}$ depth and the lobe appear to be the main depocentres of particulate input rich in organic matter derived from the Congo River.

As for the influence of the Congo River in the surface water (Vangriesheim et al., this volume-b), fresh water inputs are unbalanced in nutrients and have large excesses of silicate, relative to what phytoplankton-particularly the siliceous species such as diatomsrequires. Relations were established between salinity and DIC, $\delta^{18} \mathrm{O}$ and $\delta^{13} \mathrm{C}$ values in the 
surface waters corresponding to mixing lines between two end members: the sea-water and the Congo river fresh water. It is clearly demonstrated that the two systems of surface water and deep water are controlled by two completely different processes: the surface water is dominated by the mixing with the Congo river, whereas the deep water system is essentially controlled by the mineralization process.

\subsection{Geochemical processes at the sediment-water interface}

As for the particulate input (Rabouille et al., this volume), the daily mass fluxes at 400 meters above the sea-bottom calculated from the 4 years dataset were 123,67 and $80 \mathrm{mg} \mathrm{m}^{-2} \mathrm{~d}^{-1}$ at stations ZA, ZC and ZD respectively. At station $Z R$, the total flux was $141 \mathrm{mg} \mathrm{m}^{-2} \mathrm{~d}^{-1}$ measured during only 4 months. Close to the sea-bottom (30 meters above it), the daily mass flux was higher than at 400 meters above the sea-bottom due to sediment resuspension close to the nepheloid layer at station ZA, ZC and ZD.

The calculated average organic carbon fluxes at station ZC and ZD are comparable with trap measurements made at these depths in the mesotrophic Atlantic (Bory et al., 2001; Lampitt and Antia, 1997). They are also of the same order of magnitude than those measured by Fischer et al. (2000) and Wefer et al. (1993) at similar depths in the same region. The mean total flux measured at station ZA was also comparable with the South Atlantic model proposed by Seiter et al. (2005).

Comparison of the vertical flux of organic carbon with its mineralization and burial in the vicinity of the Congo channel (site ZD) and $200 \mathrm{~km}$ away (site ZC) reveal that the lateral input is very important (Rabouille et al., this volume). The Congo channel is an efficient conduit for river and shelf particles. The effect of the lateral transport is much bigger than the vertical input and contributes up to $85 \%$ of the organic input on the slope rise. According to Rabouille et al. (this volume), the lateral influence of the channel at a depth of $4000 \mathrm{~m}$ seems minimal as mineralization/burial fluxes are equal at distances of 15 and $200 \mathrm{~km}$ from the channel (station ZC and ZD). Results show a decreasing recycling of organic carbon when moving offshore and towards deeper waters. The large mineralization rates of organic carbon are associated with the high organic carbon content (3\%) and the large sedimentation rate (19 $\mathrm{mm} \mathrm{yr}^{-1}$ ) found at the Lobe site. This region could receive as much as $19 \mathrm{~mol} \mathrm{C} \mathrm{m}^{-2} \mathrm{y}^{-1}, 1 / 3$ being mineralized and $2 / 3$ being buried, which could result in the largest depocenter of organic carbon in the South Atlantic. The origin of the organic particles leading to the deep water anomaly is still debated. Arguments are given in favor of an input from the turbidity current sediment overflow at $\sim 4000 \mathrm{~m}$ (Vangriesheim et al., this volume-a) whilst other authors suggest that this input comes from downslope particle transport (Rabouille et al., this volume).

\subsection{Diversity and abundance of benthic communities in sedimentary environments near and far from the Congo channel}

In order to analyse the variations of the benthic community structure with depth and in areas which could be more or less influenced by the Congo river discharge, we compared the abundance and composition obtained at various stations for the meiofauna and the macrofauna

The meiofaunal communities in the Gulf of Guinea reflect heterogeneous conditions on the margin, and the multiple-scale spatial variability that corresponds to different identified habitats (Van Gaever et al., this volume). The average total meiofaunal densities were different between sites with relatively high densities on the Angola margin at $1300 \mathrm{~m}$ depth compared to the density at $4000 \mathrm{~m}$ depth $\left(1320 \pm 460\right.$ ind. $10 \mathrm{~cm}^{-2}$ at site ZA and $1005 \pm 78$ ind. $10 \mathrm{~cm}^{-2}$ at site ZC). However, sites along the Congo channel were characterized by extremely low densities ( $<20$ ind. $10 \mathrm{~cm}^{-2}$ ). The diversity of meiobenthic phylum level was high on the Angola margin with a maximum of 14 different meiobenthic taxa, and low along the canyon with a minimum of only 2 taxa (nematodes and polychaetes) on the bottom of the 
channel. Distinct meiofaunal communities could be distinguished, reflecting a multiple-scale spatial variability (from m's to $200 \mathrm{~km}$ ) that corresponds with the different habitats in the Gulf of Guinea. Sites located along the Congo Channel were obviously affected by the local highvelocity bottom currents and unstable sedimentary conditions in this active submarine system. Extremely low meiobenthic densities and very low proportions in the most surficial sediment layers provided evidence for recently highly disturbed sediments at these sites.

For the macrofauna, density, taxonomic composition at higher taxon level and vertical distribution were compared in different deep stations together with sediment characteristics (pore water, organic carbon, $\mathrm{C} / \mathrm{N}$ ratio) (Galéron et al., this volume). The deep macrofaunal communities were spatially and temporally heterogeneous in terms of structure and distribution. On the upper slope (site ZA, $1300-1500 \mathrm{~m}$ depth), characterized by an unexpected richness in organic carbon of the sediment $(2,1 \%)$ not only in the surface but down to $15 \mathrm{~cm}$, the mean density of the total macrofaunal community varied between 4800 to $6000 \mathrm{ind} / \mathrm{m}^{2}$. The community structure reflected a relatively high diversity represented by 23 different taxa and a clear dominance of polychaete worms (55\% to $59 \%$ of the total macrofauna) (Galéron et al., this volume). It corresponds to the general picture of the macrofauna composition at this taxonomic level when compared to other known deep-sea sites. Multivariate analyses showed that the macrobenthic community on the upper slope of the Angola margin was, to a certain extent, structured in space at a kilometer-scale (Brind'Amour et al., this volume), thus at a broader scale than that previously envisioned by Grassle and Sanders (1973). In the framework of environmental impact assessments in which this study took place, natural differences in community structure occurring at the same spatial scale as those that might be expected from human activities highlight the need for a better description and understanding of distribution patterns of the macrobenthos on continental margins. At the deep locations (4000 m depth) the macrofaunal communities contained relatively high densities (1300 to 4000 ind. $/ \mathrm{m}^{-2}$ ) compared with macrofaunal communities at similar depths. This was due to high levels of food input related to the Congo River and the submarine system processes that affect the whole study area. The activities of the very active Congo system structured the deep macrofaunal communities on a large area in terms of density, composition and vertical distribution. The food input was enhanced at a regional scale as well as the heterogeneity of the sediment characteristics, mainly in terms of organic matter quality (marine vs terrigenous). In turn, the densities were enhanced as well as the regional diversity of the macrofaunal communities in terms of taxonomic composition. The Congo activities, we suspect, directly or indirectly influence the sedimentary habitat conditions on a large area at abyssal depth, extending probably on hundreds of kilometers around the submarine system.

\subsection{Dynamics of the biota in sediment habitats}

The long-term colonization experiments at the upper and down slope sites (ZA and ZC) off Angola and close to the Congo canyon provided information on the influence of depth and local environment conditions on macrofaunal colonization patterns and organic carbon degradation rates. Colonization rates varied by one order of magnitude between bathyal and abyssal experiments (Menot et al., this volume). At bathyal depths, high colonization rates of a specialized fauna were among the highest recorded in the deep-sea. The specialized (opportunists) fauna might play an important role in the functioning of the ecosystem. In contrast, at abyssal depth, low colonization rates of resident fauna were observed. New recruits at bathyal depths would thus have the ability to exploit pulses of organic matter. At abyssal depths, high rates of organic matter degradation associated with low rates of colonization suggested that a pulse of organic matter would mainly benefit the resident community.

Functional differences between bathyal and abyssal benthic communities in carbon mineralization have been previously observed by short-term incubation experimentation (Witte et al., 2003). While the short term experiment concluded there are lower mineralization 
rates at abyssal depths, with a significant contribution by the macrofauna, the longer term Biozaire colonization experiments suggests that mineralization rates were independent of depth, with minor contributions by the macrofaunal at abyssal depth.

\subsection{Cold-seep biological activity}

Data on the bathymetry, sonar imagery and seismic are the prerequisite for the identification of possible active pockmarks. The geological surveys of the Gulf of Guinea allowed the biological studies to select localized structures of suspected seabed seepage.

The survey in 2000 with the ROV Victor of a large structure identified previously on side scan sonar during the Zaiango cruise in 1998 (Savoye et al., this volume) revealed a high biological colonization of fauna belonging to families known to be indicators of seeps. When the first dive of ROV Victor was done during the Zaiango-Rov cruise in December 2000 geologists and biologists onboard the R/V l'Atalante discovered this giant pockmark called Regab, located at $3160 \mathrm{~m}$ depth, $8 \mathrm{~km}$ north from the deep Congo channel (Ondréas et al., 2005; Sibuet et al., 2002). This cold seep area of $800 \mathrm{~m}$ in diameter, is the first to be described in the Equatorial East Atlantic and the second in size in the Eastern Atlantic after the Haakon Mosby Mud Volcano located in the Norvegian Sea (Gebruk et al., 2003). It is characterized by distinct assemblages and habitats, dominated either by Mytilidae or Vesicomyidae bivalves or by Siboglinidae polychaetes, or bacterial mats. The most active zone was in a depression with abundant carbonate concretions and high methane fluxes where high-density clusters of mussels and siboglinids dominated (Olu-Le Roy et al., 2007)..

\subsubsection{Microbial activity}

Sediment cores collected inside the Regab pockmark area in all the different type of faunal assemblages were analysed for their lipid biomarker distribution and associated stable carbon isotopic composition. ${ }^{13} \mathrm{C}$-depleted archaeal and bacterial biomarkers were abundant in sediment cores, revealing Anaerobic Oxidation of Methane (AOM) coupled to sulphate reduction (Bouloubassi et al., this volume). AOM is mediated by archaea, operating most likely in cooperation with sulphate reducing bacteria (Boetius et al., 2000) These coupled processes contribute to the sink of methane and production of hydrogen sulfide. Substantial amounts of archaeal lipids were found; all archaeal lipids were profoundly depleted in ${ }^{13} \mathrm{C}$. The structural and isotopic patterns of these microbial lipids provided evidence for anaerobic oxidation of methane (AOM). Biomarker depth profiles show that AOM occurs mainly 6 to 12 $\mathrm{cm}$ below the surface of sediment.

The biomarker evidence for AOM and associated microbial consortia is consistent with results from a molecular biology study performed in the same setting. Indeed, the microbial diversity in sediments from four different assemblages of chemosynthetic organisms, Mytilidae, Vesicomyidae, Siboglinidae and a bacterial mat, was investigated using comparative 16S rRNA gene sequence analysis. Aggregates of anaerobic methanotrophic archaea (ANME-2) and bacteria of the Desulfosarcina/Desulfococcus cluster were found in all four chemosynthetic habitats. Highest densities of AOM consortia were discovered at the Mytilidae sites, which also showed the highest methane concentrations in the bottom waters. Cambon...

Active $\mathrm{AOM}$ at the Regab pockmark sustains the dense chemosynthetic assemblages observed on the seafloor and favours authigenic carbonate precipitation (Pierre and Fouquet, 2007).

\subsubsection{Cold seep benthic fauna}

The Regab cold seep sediments were colonized by meiobenthic and macrobenthic communities. Meiofaunal abundances within the Regab seep varied between 20 ind. $10 \mathrm{~cm}^{-2}$ and 873 ind. $10 \mathrm{~cm}^{-2}$ (Van Gaever et al., this volume). The meiobenthos was characterized 
by small-scale (m's) patchiness, low species richness and the dominance of Sabatieria mortenseni a cosmopolitan nematode indicator for anoxic to sub-oxic sediments. The large size, the high individual body weight and the dominance of this species at the cold seep site resulted in a significantly higher nematode biomass at the seep compared to the surrounding sites.

The macrofauna sampled near each habitat and in the surrounding environments still need to be analyzed at the taxa level. The general pattern of abundance indicates a high heterogeneity in abundances: with mean densities exceptionally high near mytilid aggregates ( $25000 \mathrm{ind} / \mathrm{m}^{2}$ ), ten times more than near a vesicomyid field $\left(2700 \mathrm{ind} / \mathrm{m}^{2}\right.$ ) whereas outside the pockmarks the abundance reach only $1500 \mathrm{ind} / \mathrm{m}^{2}$ which corresponds to the densities found elsewhere at that depth.

The Regab's striking feature was the abundance and diversity of large bivalves and tube worms. The observed megafauna communities were organized in clusters of large organisms belonging to bivalves families, Vesicomyidae, Mytilidae (Olu-Le Roy et al., 2007; Ondréas et al., 2005). There were also bushes of pogonophoran tube worms. The Regab pockmark is an unusual cold-seep site by the high spatial heterogeneity of habitats in a relatively restricted area, which makes comparisons easier between habitats and chemosynthetic assemblages. Thus, it is possible to identify the factors controlling the community structure at a relatively small scale. Whereas the ecology studies on the spatial distribution begun with video analyses (Olu-Le Roy et al., 2007) and limited taxonomic identification, the taxonomic studies are essential to further study the species diversity and abundance in this particular habitat.

Taxonomic studies of organisms collected at the Regab site, already published or in this volume provided identifications of the following species:

One new species of siboglinid polychaete Escarpia southwardae $n$. sp. (Andersen et al., 2004);

Four Vesicomyidae species which are new to science. They belong to 4 distinct genera, one of which is new to science (Cosel and Olu, this volume, 2008) .

One species of Mytilidae species, Bathymodiolus sp. aff. Boomerang (Olu-Le Roy et al., 2007).

These species belong to a family known to be directly linked to chemosynthesis processes through the symbiotic association with either methanotrophic or sulphide-oxidizing bacteria. Symbiosis is known to be of prime importance in the productivity of cold seep communities (Sibuet and Olu-Le Roy, 2002; Sibuet and Olu, 1998). The availability of energy in the form of methane and sulfide to the symbiosis is a key parameter for distribution and structure of communities. It was therefore essential to characterize the type of associations and when possible to search with possible response to the chemical background.

The symbiosis in the tube worm was investigated and preliminary results based on electron micrographs suggested the presence of sulphide-oxidizing symbionts (Andersen et al., 2004) which has now been confirmed (Cambon Bonavita et al., this volume).

Specimens of the mytilid Bathymodiolus sp. have been analysed to identify the nature of the symbionts and their distribution. Transmission electron microscopy, comparative 16S rRNA analysis, and fluorescence in situ hybridization indicated that this Bathymodiolus $\mathrm{sp}$. aff boomerang lives in a dual symbiosis with sulfide- and methane-oxidizing bacteria (Cambon Bonavita et al., this volume; Duperron et al., 2005). A distinct distribution pattern of the symbiotic bacteria in the gill epithelium was observed, with the thiotrophic symbiont dominating the apical region and the methanotrophic symbiont more abundant in the basal region of the bacteriocytes (Duperron et al., 2005). The symbiont distribution, as discussed by the authors, may reflect the dependence on exchanges with the mantle fluids considering that the sulfide concentrations in the seawater at the collection site were much lower than the methane concentrations.

A single phylotype, related to a sulphide-oxidizing endosymbiont, was recovered from a vesicomyid clam (Cambon Bonavita et al., this volume). 
The rich chemosynthetic fauna create a favorable environment for associated fauna which are attracted by this typical environment and are more or less endemic to seep (Carney, 1994). Many other deep-sea fauna have been observed and sampled when possible with the ROV Victor 6000 at the REGAB site, Gastropoda, crustaceans, (mainly shrimps), echinoderms (mainly holothurians) and fishes (Zoarcidae and Ophidiidae. The taxonomic studies presented in this volume and recently published show that a great number of species are new to science or known from other seep region in western Atlantic.

- Gastropods are represented at Regab by 10 new species including one new genus (Warén and Bouchet, this volume). They belong to distinct subclasses, patellogastropoda (the limpet paralepetopsis usually fixed on mussels or tube worms) cocculiniformia, Vetigastropoda (Lepetodrillidae), Neophalina, Caenogastropoda (Provannidae which includes a new genus), and Conidae. These subclasses and families are represented in other seeps (Sibuet and Olu, 1998). Waren and Bouchet (this volume) introduced an interesting discussion showing the limit of the understanding of evolution of these families which colonize chemosynthetic environments.

- Alvinocarid shrimps are represented by one species Alvinocaris muricola Williams, 1988 (Komai and Segonzac, 2005) also known from Barbados and West Florida escarpment seeps. It is observed in high densities (300 to 750 ind. $\mathrm{m}^{-2}$ ) in the chemosynthetic clusters and contributes to a large part (10 to 25\%) of the total biomass (Olu et al., this volume). Ramirez and Segonzac + ref Endnote 2006 studied the reproductive strategy of this species for which planktotrophic larvae may explain their presence in geographically distant seeps.

Galatheid crabs are represented by Munidopsis geyeri Pequegnat and Pequegnat, 1970 (Macpherson and Segonzac, 2005)

Holothuroids are observed in exceptional high number. The study of the anatomy and the spicules allows to consider their belonging to the family Synaptidae with a very close resemblance to Chiridota heveva Pawson \& Vance, 2004, inhabitant of Western Atlantic (Florida Escarpment -3266 m depth, Blake ridge 2200 m depth and east of Savannah) deep cold seeps and anthropogenic (wood) habitats.

The associated species, which are likely endemics or vagrants of the seep community, mainly use chemosynthesis-derived carbon but with variable contribution of methanotrophy or thiotrophy (Olu et al., this volume). The total biomass was dominated by primary "consumers", (symbiont-bearing species and feeders of free living microbes, such as shrimps and gastropods). Scavengers and predators (galatheids, and zoarcid fishes) representing the higher trophic levels are less densely distributed but occur all over the area colonized by chemosynthetic assemblages. The Regab community in general bears a high resemblance with seeps in the western Atlantic (Barbados prism, Gulf of Mexico, Blake Ridge).

Other smaller pockmarks and diapirs (mud volcanoes) were surveyed with the ROV Victor in 2001 near Gabon (site Guiness) and on the Angola slope (site Diapir). While no seep activity was revealed at the Diapir site, chemosynthetic taxa, reduced sediment, and isolated carbonate concretions have been observed at the site Guiness colonized by Vesicomyidae clams and Lucinidae. Sampling with ROV at the Guiness site provided material to describe one new genus and two new species Graecina karinae n. gen., and n. sp. Lucinoma myriamae n. sp.. (Cosel, 2006). However, the seep activity appeared low and dispersed on the Guiness site.

Seeps affect punctually and everywhere the deep Gulf of Guinea but until now only the large Regab site is really spectacular and propitious to several research subjects.

\subsection{Cold coral reefs}

While shallow-water reefs are common and well-known features in the northeast Atlantic (Freiwald, 2002), very few records of deep-water corals reefs exist at low latitudes, and the supposed existence of them have been deduced from trawl or dredge samples. In the Gulf of Guinea, the presence of deep-sea coral Lophelia pertusa was first reported close to the Congo canyon at a depth of $380 \mathrm{~m}$ during the 1950 Galathea cruise (Zibrowius, 1980). This 
cosmopolitan species was known from past oceanographic cruises and one industrial ROV survey. Multibeam bathymetry, side-scan sonar, high-resolution seismics and finally ROV Victor dives in 2001 at site ZB revealed the occurrence of large mounds built by L. pertusa and associated megafauna mainly fishes (Le Guilloux et al., this volume). The reef-building scleractinian coral Lophelia pertusa has colonized carbonate mounds that reach heights of ca. $30 \mathrm{~m}$ and follow an orientation that is correlated with salt tectonic features. The coral field covers a $6 \times 2 \mathrm{~km}$ area and is parallel to a normal fault. Geological setting and biological observations are used to discuss the co-occurrence of cold seeps and cold-water corals. The coral developed on elevated topographic features initiated by tectonic processes. Whereas the reef community nutrition is dependant of the detritical food chain, reducing sediments colonized by lucinid shells characterize the closed environment of the coral mounds. Three new species have been described after shells collected on a relatively flat area of relatively dark (reduced) sediment not far from the mounds:Graecina karinae n. sp., Lucinoma myriamae n. sp., Joellina dosiniformis n. sp. (Cosel, 2006). These particular conditions are likely to be related to fluid seepages that commonly occur along the whole margin and have not direct relation with the feeding of coral reefs, which probably benefit at the beginning of their formation of a hard substrate due to the bio-mineralization.

\section{Conclusion}

The long-term program initiated in the equatorial West African margin allowed analysis of natural, spatial and temporal variations of the environment. The survey and integrated experiments undertaken at a regional scale from $350 \mathrm{~m}$ to $4800 \mathrm{~m}$ depth provided (1) description of newly discovered benthic habitats, deep-sea corals and localized rich biological communities associated with seeps, and (2) documentation of the degree to which the variations of the benthic community structure could be influenced by the Congo river discharge. Taxonomic studies dedicated to the seep environment described 16 new species, including two 2 new genera, along with three new species in the vicinity of the corals.. Symbiosis has been demonstrated for almost all the chemosynthetic species collected. Integrated studies on the large Regab pockmark area provide a comprehensive picture of the quantitative and qualitative distribution of the meio, macro and megafauna communities in relation to methane concentration and biological interactions.

The records of unexpected events show that the Congo channel is a very active system with highly energetic turbidity currents causing rapid transport of large quantities of sediment as far as the Lobe area at $4800 \mathrm{~m}$ depth. The consequence of this discharge and its overflow in the distal part of the channel on the spatial and temporal change of the environmental conditions and biological response is an interesting question, which merits a debate. It has been clearly demonstrated that the two systems of surface and deep waters are controlled by two completely different processes: the surface water is dominated by mixing of the seawater and the Congo River water whereas the deep water system is essentially controlled by the mineralization process. The deep-water layer at $4000 \mathrm{~m}$ depth is characterized by anomalies in oxygen (decrease), silicates and nutrients (increase), which were explained by re-mineralization of particulate organic matter and upward diffusion of the silicate from the sediment. The origin of the organic particles leading to the deep-water anomalies was attributed to turbidity currents and the sediment overflow in the deep domain. The consequence on all benthic processes is still not elucidated completely. Rather than the overflow of particles from the channel, the downslope particle transport in this region influenced by high surface primary productivity has been suggested as an explanation of the high oxygen demand and the variation of structure and abundance of the benthic fauna, which does not necessarily reflect a direct link with turbiditic events. The temporal and spatial variability are remarkably complex in this region, and direct relationships between the benthic response to episodic phenomena as well as rich input coming from cross-slope transport processes remain to be elucidated. 
The accomplished work was possible through cooperation of the following scientists of several institutions who participated to cruises of the project Biozaïre:

Ifremer: Aprioual R., Bousquet T A., Branellec P., Brulport J.-P., Caprais J.-C., Cochonat P., Crassous P. Fabri, M.-C., Fifis A., Galéron J., Gay A., Gouillou J-P., Khripounoff A., Le Bris N., Menot L., Nadalig T., Noel P., Olu K., Ondreas H., Rodier, P. Savoye B., Segonzac M.

CNRS : Bouloubassi I., Pierre C. ,, Treignier,C., Bombled B.

IRD : Baurand F.

CEA : Dedieu K.

IUEM : Gallinari M.

MNHN : Von Cosel R., Iglesias S.

Elf Norvegia : Borseth J., F. Pinturier L.

University Paris 6 (Roscoff laboratory) : Andersen A.

Sonangol : Dos Santos M.

Total : Durieux J.

University of Gent : Van Gaever S.

E.K.Th.E, Grece : Presti, M.

INGV, Roma: Lo Bue N.

\section{Acknowledgements}

The BIOZAIRE project was a scientific project conducted by Ifremer in partnership with TOTAL. The Biozaire project followed the Zaiango project leaded in geosciences by Bruno Savoye. We express our sadness as during the preparation of this volume we learned the accidental death of Bruno Savoye. An obituary is given in the next page. We wish to thank the cruise participants and the scientists who collaborate to the project. Many thanks to those who contributed to this special volume of Deep Sea Research and to M.-C. Fabri in charge of the Ifremer data base BIOCEAN (www.ifremer.fr/biocean) and who was very helpful by providing maps and metadata to all contributors of this volume.. Special thanks are expressed to TOTAL colleagues from the Environment Department of Total Exploration \& Production: Jacques Desneulin who welcomed the first presentation of this scientific project at Pau in 1998, Jacques Miné who follows with interest the results obtained after each cruise, Jean-François Vidalie and Roger Camps who encouraged the collaboration between Ifremer and Total; Denis Levache who contributed to chemical analyses, Josiane Durrieu, engineer at Total who participated to BIOZAIRE 1 cruise; we were sad to learn that she passed away in March 2009.

We thank the captains, the officers and the crew of the Research Vessels, N/O L'Atalante, Thalassa, Le Suroit, Beautemps-Beaupré and the ROV Victor team who contributed to the success of Victor dives in its early stage by resolving engine failures during the cruise.

We wish to acknowledge John Milliman who help us to prepare this special volume and our CoML-COMARGE colleagues Robert Carney and Gilbert Rowe who reviewed the maunuscript. The biological results contribute to the project COMARGE( Continental Margin Ecosystems on a world wide scale) of the International Program Census of Marine Life.

\section{References}

Andersen, A.C., Hourdez, S., Marie, B., Jollivet, D., Lallier, F.H., Sibuet, M., 2004. Escarpia southwardae sp. nov., a new species of vestimentiferan tubeworm (Annelida, Siboglinidae) from West African cold seeps. Canadian Journal of Zoology 82, 980-999.

Arhan, M., Mercier, H., Bourlès, B., Gouriou, Y., 1998. Hydrographic sections across the Atlantic at $7^{\circ} 30 \mathrm{~N}$ and $4^{\circ} 30 \mathrm{~S}$. Deep-Sea Research I 45, 829-872. 
Babonneau, N., Savoye, B., Cremer, M., Klein, B., 2002. Morphology and architecture of the present channel system of Zaire Deep-Sea Fan. Marine and Petroleum Geology 19 (4), 445467.

Boetius, A., Ravenschlag, K., Schubert, G.J., Rickert, D., Widdel, F., Gieseke, A., Amann, R., Jorgensen, B.B., Witte, U., Pfannkuche, O., 2000. A marine microbial consortium apparently mediating anaerobic oxidation of methane. Nature 407, 623-626.

Bory, A., Jeandel, C., Leblond, N., Vangriesheim, A., Khripounoff, A., Beaufort, L., Rabouille, C., Nicolas, E., Tachikawa, K., Etcheber, H., Buat-Ménard, P., 2001. Downward particle fluxes within different productivity regimes off the Mauritanian upwelling zone (EUMELI program). Deep-Sea Research I 48, 2251-2282.

Bouloubassi, I., Nabais, E., Pancost, R.D., Lorre, A., Taphanel, M.H., this volume. First biomarker evidence for methane cycling at cold seeps in the South East Atlantic (REGAB pockmark). Deep Sea Research II.

Brind'Amour, A., Menot, L., Galeron, J., Crassous, P., this volume. Spatial organization of a sedimentary macrobenthic community located on the West African Equatorial margin. Deep Sea Research II.

Cahet, G., Sibuet, M., 1986. Activité biologique en domaine profond : transformations biochimiques in situ de composés organiques marqués au carbone 14 à l'interface eausédiment par 2000 m de profondeur dans le Golfe de Gascogne. Marine Biology 90, 307315.

Cambon Bonavita, M.A., Nadalig, T., Roussel, E., Delage, E., Olu , K., Duperron, S., Caprais, J.C., Boetius, A., Sibuet, M., this volume. Diversity and distribution of methane oxidizing microbial communities associated with different faunal assemblages in a giant pockmark of the Gabon continental margin. Deep Sea Research II.

Carney, R.S., 1994. Consideration of the oasis analogy for chemosynthetic communities at Gulf of Mexico hydrocarbon vents. Geo-Marine Letters 14, 149-159.

Cosel, R.V., 2006. Taxonomy of tropical West African bivalves. VI. remarks on Lucinidae (Mollusca, Bivalvia), with description of six new genera and eight new species. Zoostystema 28 (4), 805-851.

Cosel, R.v., Olu, K., this volume. Large Vesicomyidae (Mollusca: Bivalvia) from cold seeps in the Gulf of Guinea off the coasts of Gabon, Congo and northern Angola. Deep Sea Research II.

Cosel, R.v., Olu, K., . 2008. A new genus and new species of Vesicomyidae (Mollusca: Bivalvia) from cold seeps on the Barbados accretionary prism, with comments on other species. Zoostystema 30 ((4): ), 929-944.

Duperron, S., Nadalig, T., Caprais, J.C., Sibuet, M., Fiala-Médioni, A., Amann, R., Dubilier, N., 2005. Dual symbiosis in a Bathymodiolus sp mussel from a methane seep on the gabon continental margin (southeast Atlantic): 16S rRNA phylogeny and distribution of the symbionts in gills. Applied and Environmental Microbiology 71 (4), 1694-1700.

Fabri, M.-C., Galeron, J., Larour, M., Maudire, G., 2006. Combining the Biocean database for deep-sea benthic data and online Ocean Biogeographic Information System. Marine Ecology Progress Series 316, 215-224.

Fischer, G., Ratmeyer, V., Wefer, G., 2000. Organic carbon fluxes in the Atlantic and the Southern Ocean: relationship to primary production compiled from satellite radiometer data. Deep Sea Research II 47, 1961-1997.

Freiwald, A., 2002. Reef-forming cold-water corals. In: G Wefer, D.B., D Hebbeln, BB Jorgensen, M Schluter, TCE van Weering (Ed.), Ocean Margin Systems. Springer, Heidelberg, pp. 365-385.

Galéron, J., Menot, L., Renaud, N., Crassous, P., Khripounoff, A., Treignier, C., Sibuet, M., this volume. Spatial and temporal patterns of benthic macrofaunal communities on the deep continental margin in the Gulf of Guinea. Deep Sea Research II.

Gebruk, A., Krylova, E.M., Lein, A., Vinogradov, G.M., Anderson, E., Pimenov, N.V., Cherkashev, G.A., Crane, K., 2003. Methane seep community of the Hakon Mosby mud volcano the Norvegian Sea: composition and trophic aspects. Sarsia 88 (6), 394-403. 
Grassle, J.F., Maciolek, N.J., 1992. Deep-sea species richness: regional and local diversity estimates from quantitative bottom samples. American Naturalist 139, 313-341.

Grassle, J.F., Sanders, H.L., 1973. Life histories and the role of disturbance. Deep-Sea Research 20, 643-659.

Guiavarc'h, C., 2007. Modélisation haute-résolution des courants dans le Golfe de Guinée : Etude des oscillations bimensuelles. Thèse de doctorat, Université de Bretagne Occidentale, Brest.

Guiavarc'h, C., Tréguier, A.M., Vangriesheim, A., 2008. Remotely forced biweekly deep oscillations on the continental slope of the Gulf of Guinea. Journal of Geophysical Research 113, C06002 (doi: 10.1029/2007JC004471).

Khripounoff, A., Vangriesheim, A., Babonneau, N., Crassous, P., Denniellou, B., Savoye, B., 2003. Direct observation of intense turbidity activity in the Zaire submarine valley at $4000 \mathrm{~m}$ water depth. Marine Geology (194), 151-158.

Komai, T., Segonzac, M., 2005. A revision of the genus Alvinocaris Williams and Chace (Crustacea: Decapoda: Caridea: Alvinocaridea), with descriptions of a new genus and a new species of Alvinocaris. Journal of Natural History 39 (15), 1111-1175.

Lampitt, R.S., Antia, A.N., 1997. Particle flux in deep seas : regional characteristics and temporal variability. Deep-Sea Research 44 (8), 1377-1403.

Le Guilloux, E., Olu, K., Bourillet, J.F., Savoye, B., Iglesias, S., Sibuet, M., this volume. First observation of deep-sea coral reef along the Angola margin. Deep Sea Research II.

Macpherson, E., Segonzac, M., 2005. Species of the genus Munidopsis (Crustacea, Decapoda, Galatheidae) from the deep Atlantic Ocean, including cold-seep and hydrothermal vent areas. Zootaxa, 1-60.

Menot, L., Crassous, P., Desbruyères, D., Galeron, J., Khripounoff, A., Sibuet, M., this volume. Colonization patterns along the equatorial West African margin: Implications for functioning and diversity maintenance of bathyal and abyssal communities. Deep Sea Research II.

Olu-Le Roy, K., Caprais, J.C., Fifis , A., Fabri , M.C., Galéron, J., Budzinski, H., Le Ménach, K., Khripounoff, A., Ondréas, H., Sibuet, M., 2007. Cold seep assemblages on a giant pockmark off West Africa: spatial patterns and environmental control. Marine Ecology 28, 115-130.

Olu, K., Caprais, J.C., Galéron, J., Causse, R., Cosel, R.v., Budzinsky , H., Le Ménach, K., Le Roux, C., Levaché, D., Khripounoff, A., Sibuet, M., this volume. Influence of seep emission on the non symbiont-bearing fauna and vagrant species at an active giant pockmark in the Gulf of Guinea (Congo-Angola margin). Deep Sea Research II.

Ondréas, H., Olu, K., Fouquet, Y., Charlou, J., Gay, A., Dennielou, B., Donval, J., Fifis, A., Nadalig, T., Cochonat, P., Cauquil, E., Bourillet, J., Moigne, M., Sibuet, M., 2005. ROV study of a giant pockmark on the Gabon continental margin. Geo-Marine Letters 25 (5), 281.

Pierre, C., Fouquet, Y., 2007. Authigenic carbonates from methane seeps of the Congo deep-sea fan. Geo-Marine Letters 27, 249-257.

Rabouille, C., Caprais, J.-C., Lansard, B., Crassous, P., Dedieu, K., Reyss, J.-L., Khripounoff, A., this volume. Organic matter budget in the Southeast Atlantic continental margin close to the Congo Canyon: In situ measurements of sediment oxygen consumption. Deep Sea Research II.

Rabouille, C., Gaillard, J.F., Sibuet, M., Beaucaire, C., Bonte, P., Crassous, P., Jahnke, R., Khripounoff, A., Legeleux, F., Laureillard, J., Méjanelle, L., Pierre, C., Relexans, J.C., Reyss, J.L., 1993. Sediment geochemistry in the three Eumeli sites in the Tropical Northeast Atlantic: general presentation and first results. Annales de l'Institut Océanographique 69, 3642.

Ragueneau, O., Regaudie-de-Gioux, A., Moriceau, B., Gallinari, M., Vangriesheim, A., Baurand, F., Khripounoff, A., this volume. A benthic Si mass balance on the Congo margin: origin of the 4,000 m DSi anomaly and implications for the transfer of Si from land to ocean. Deep Sea Research II. 
Savoye, B., Babonneau, N., Denniellou, B., Bez, M., this volume. Geological overview of the Angola-Congo Margin: The Congo deep-sea fan and its submarine valleys. Deep Sea Research II.

Savoye, B., Cochonat, P., Apprioual, R., Bain, O., Baltzer, A., Bellec, V., Beuzart, P., Bourillet, J.F., Cagna, R., Cremer, M., Crusson, A., Dennielou, B., Diebler, D., Droz, L., Ennes, J.C., Floch, G., Guiomar, M., Harmegnies, F., Kerbrat, R., Klein, B., Kuhn, H., Landuré, J.Y., Lasnier, C., Le Drezen, E., Le Formal, J.P., Lopez, M., Loubrieu, B., Marsset, T., Migeon, S., Norland, A., Nouzé, H., Ondréas, H., Pelleau, P., Saget, P., Séranne, M., Sibuet, J.C., Tofani, R., Voisset, M., 2000. Structure et évolution récente de l'éventail turbiditique du Zaïre : premiers résultats scientifiques des missions d'exploration ZaïAngo 1 \& 2 (marge congo-angola). Comptes-Rendus de l'Académie des Sciences de Paris, Sciences de la Terre et des Planète 331, 211-220.

Seiter, K., Hensen, C., Zabel, M., 2005. Benthic carbon mineralization on a global scale. Global Biogeochemical Cycles 19, 49-74.

Sibuet, M., Albert, P., Charmasson, S., Deming, J., Dinet, A., Galeron, J., Guidi-Guilvard, L., Mahaut, M.L., participants, C., 1993. The benthic ecosystem in the three Eumeli sites in the northeast tropical Atlantic: general perspectives and initial results on biological abundance and activities. Annales de l'Institut Océanographique 69, 21-33.

Sibuet, M., Floury, L., Alayse-Danet, A.-M., Echardour, A., Le Moign, T., Perron, R., 1990. In situ experimentation at the water-sediment in the deep-sea : 1 . Submersible experimental instrumentation developed for sampling and incubation. Angel M. \& M. Sibuet (Eds). Prog. Oceanogr 24, 161-168.

.Sibuet, M., Galeron, J., Khripounoff, A., Menot, L., Olu-Le Roy, K., Durrieu, J., Miné, J., Caprais, J.C., Crassous, P., Fabri, M.C., Vangriesheim, A., Desneulin, J., Savoye, B., Cochonat, P., Ondréas, H., Etoubleau, J., Loubrieu, B., Dinet, A., Von Cosel, R., 2002. Deep-Sea ecosystems on the Equatorial African Margin: First results on a pluridisciplinary environmental programme and discovery of chemosynthetic based ecosystem. Proceedings of the Sixth international conference on health, safety \& environmental in Oil and Gas exploration and production, Kuala-Lumpur, $16 \mathrm{p}$.

Sibuet, M., Olu-Le Roy, K., 2002. Cold Seep Communities on Continental Margins: Structure and Quantitative Distribution Relative to Geological and Fluid Venting Patterns. In: G. Wefer, D.B., D. Hebbeln, B.B. Jorgensen, T. Van Weering (Ed.), Ocean Margin Systems. Springer Verlag, Berlin, pp. 235-251.

Sibuet, M., Olu, K., 1998. Biogeography, biodiversity and fluid dependence of deep-sea coldseep communities at active and passive margins. Deep-Sea Research II 45, 517-567.

Thiele, J., Jaeckel, S., 1931. Muscheln der Deutschen Tiefsee-Expedition. Wissenschaftliche Ergebnisse der Deutschen Tiefsee-Expedition auf dem Dampfer "Valdivia". Gustav Fischer, Jena, pp. 159-268, 155 pls.

Van Bennekom, A.J., 1996. Silica signals in the South Atlantic. In: Wefer, G., Berger, W.H., Webb, D.J. (Eds.), The South Atlantic: Present and Past Circulation. Springer-Verlag, Berlin, pp. 345-354.

Van Bennekom, A.J., Berger, G.W., 1984. Hydrography and silica budget of the Angola Basin. Netherlands Journal of Sea Research 17 (2-4), 149-200.

Van Gaever, S., Galéron, J., Sibuet, M., Vanreusel, A., this volume. Deep-sea habitat heterogeneity influence on meiofaunal communities in the Gulf of Guinea. Deep Sea Research II.

Vangriesheim, A., Khripounoff, A., Crassous, P., this volume-a. Turbidity events observed in situ along the Congo submarine channel. Deep Sea Research II.

Vangriesheim, A., Pierre, C., Aminot, A., Metzl, N., Baurand, F., Caprais, J.-C., this volumeb. The influence of the Congo river discharges in the surface and deep layers of the Gulf of Guinea. . Deep Sea Research II.

Vangriesheim, A., Tréguier, A.M., André, G., 2005. Biweekly current oscillations on the continental slope of the Gulf of Guinea. Deep-Sea Research I 52 (11), 2168-2183.

Warén, A., Bouchet, P., this volume. New gastropods from deep-sea hydrocarbon seeps off West Africa. Deep Sea Research II. 
Warren, B.A., Speer, K.G., 1991. Deep circulation in the eastern South Atlantic ocean. DeepSea Research 38 (1), 281-322.

Wefer, G., Fischer, G., 1993. Seasonal patterns of vertical particle flux in equatorial and coastal upwelling areas of the eastern Atlantic. Deep-Sea Research I 40 (8), 1613-1645.

Witte, U., Aberle, N., Sand, M., Wenzhöfer, F., 2003. Rapid response of deep-sea benthic community to POM enrichment: an in situ experimental study. Marine Ecology Progress Series 251, 27-36.

Zibrowius, H., 1980. Les scléractiniaires de la Méditerranée et de l'Atlantique nord-oriental. Memoire de l'institut océanographique 11, 247pp.

\section{Figures}

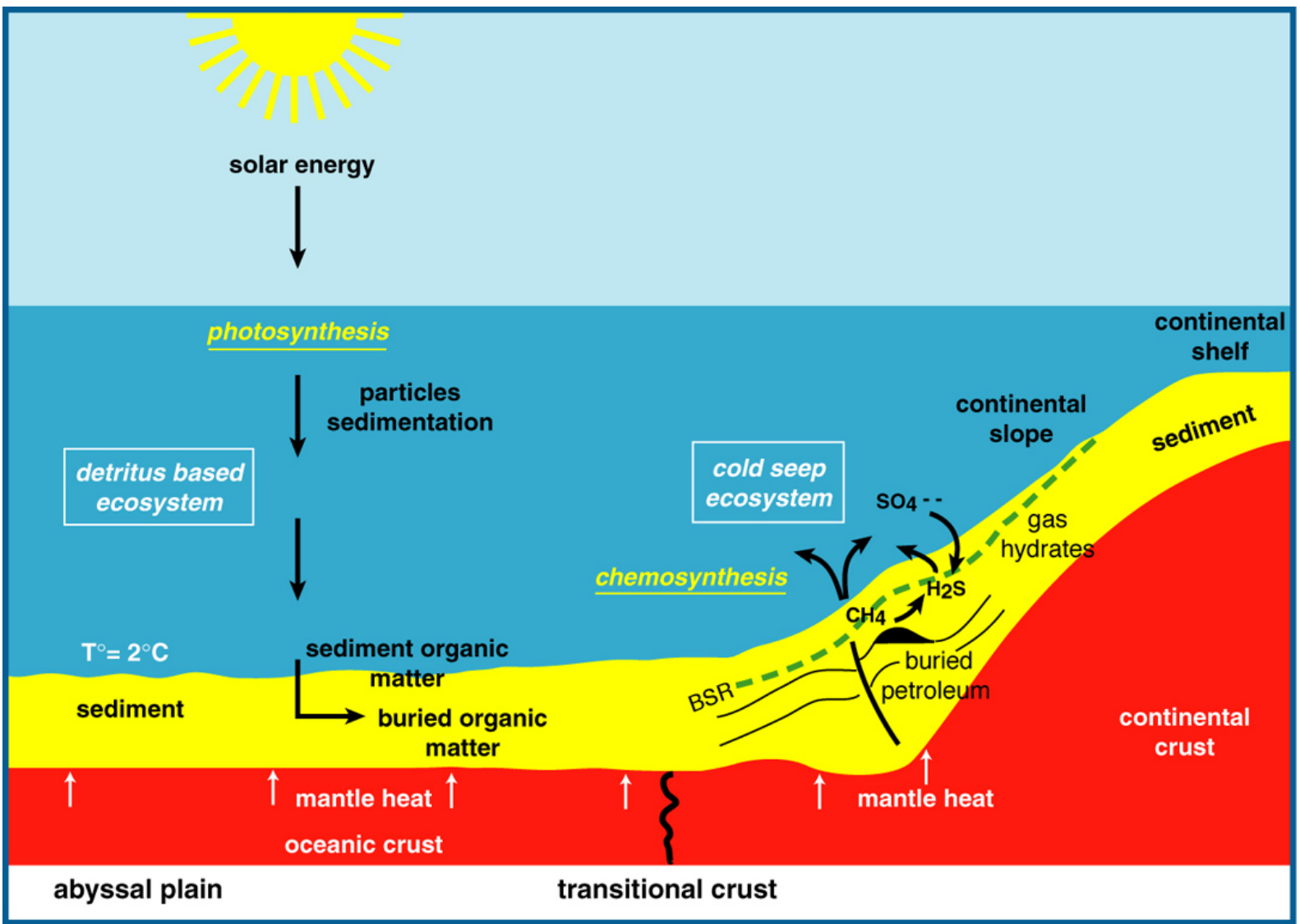

Figure 1.

Diagramme showing the environmental context of passive margin ecosystems driven by different sources of energy. 


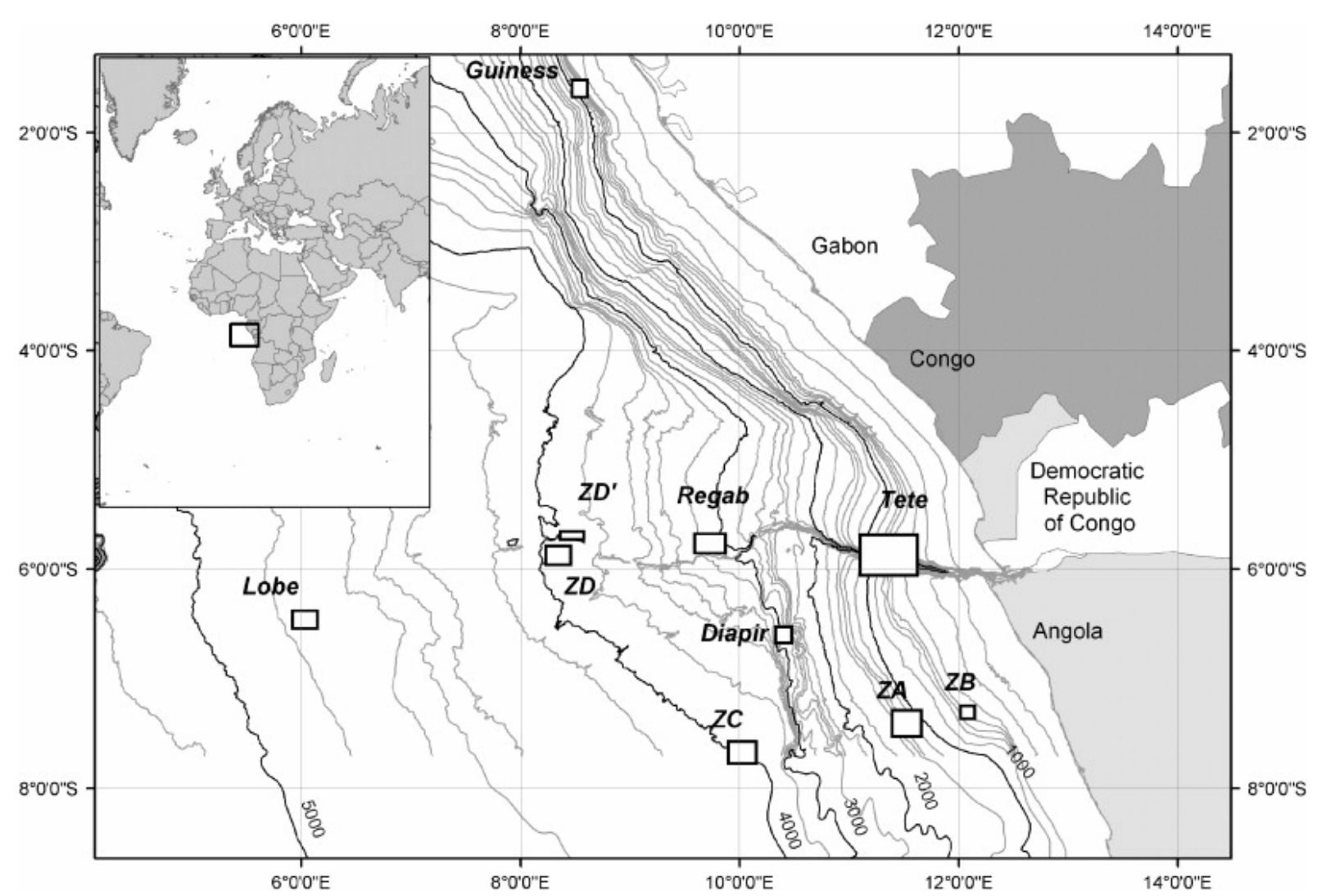

Figure 2.

Bathymetric map of the area studied during the cruises which contributed to the BIOZAIRE program in the Gulf of Guinea (rectangle in the inset map). The rectangles are areas that were intensively studied. Isobath depths are given in meters."

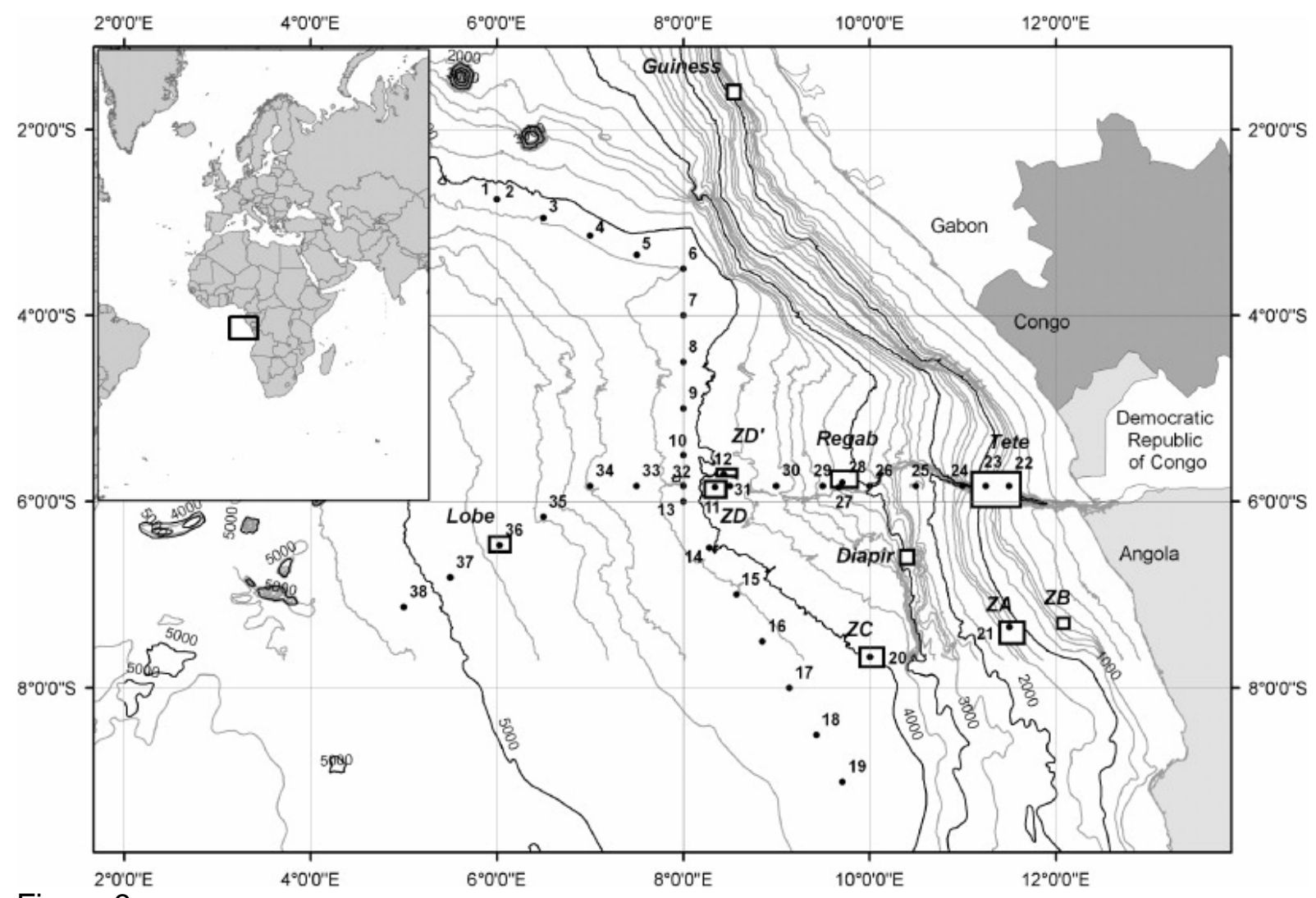

Figure 3. 
Bathymetric map of the area studied during the BIOZAIRE program with locations of the CTD-O2 stations (numbered from 1 to 38) performed during the BIOZAIRE3 cruise (December 2003 - January 2004)."

(A)

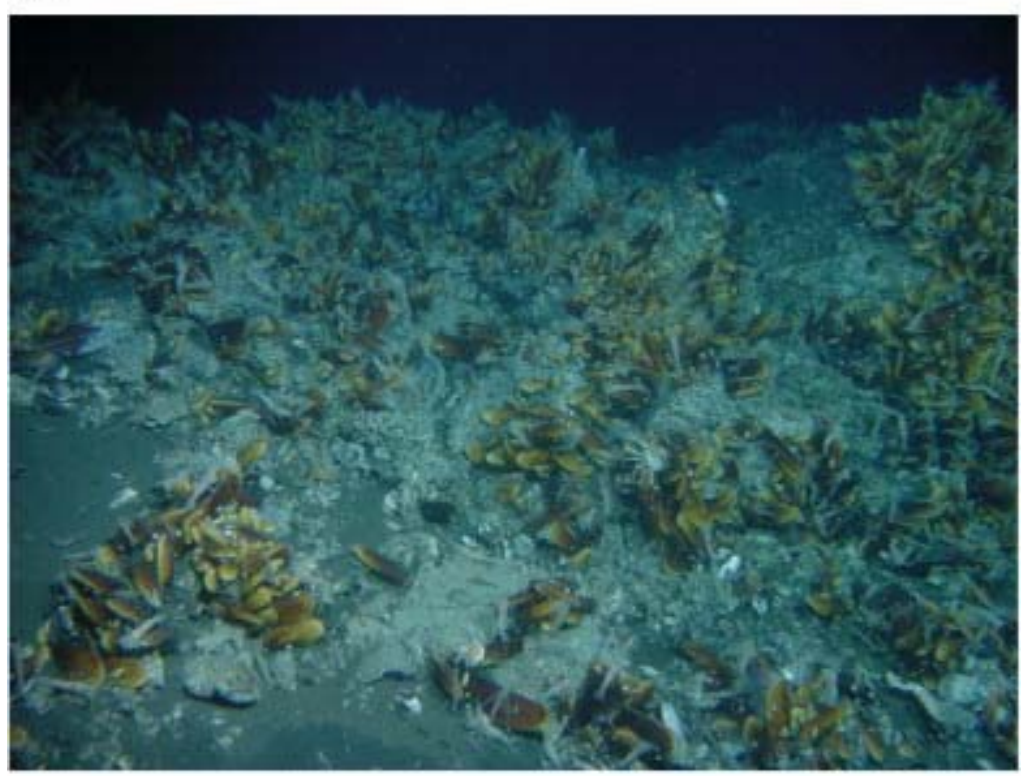

(B)

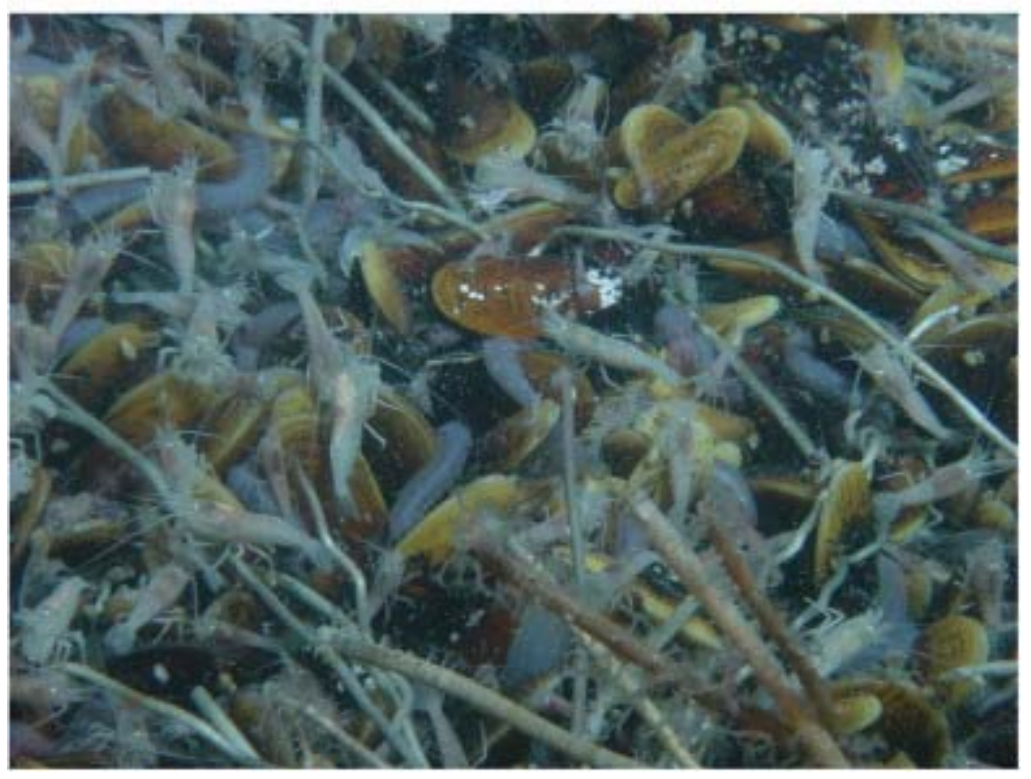

Figure 4.

Sea floor pictures on a pockmark area (Regab site) obtained during the Ifremer BIOZAIRE 2 cruise with the ROV Victor 6000 on board l'Atalante: (A) Large cold seep Mytilidae (Bathymodiolus sp. aff. boomerang) clusters; (B) a detailed picture with associated fauna, shrimps (Alvinocaris muricola), holothurians (Chiridota sp. aff. heveva, small gastropods. 
(A)

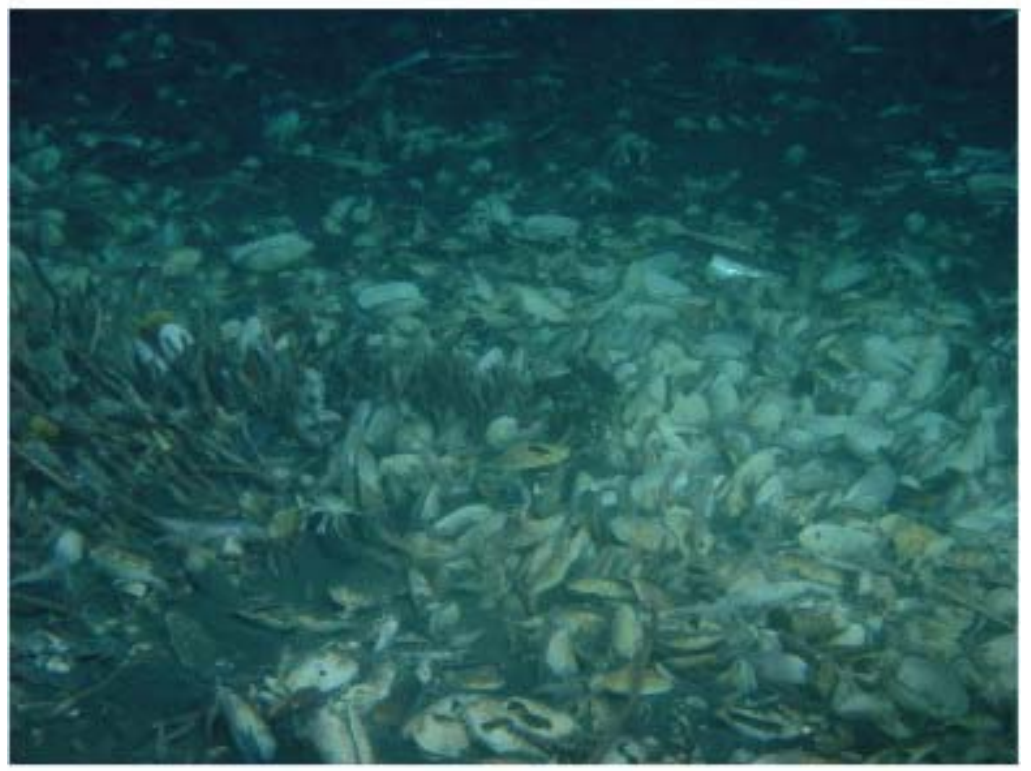

(B)

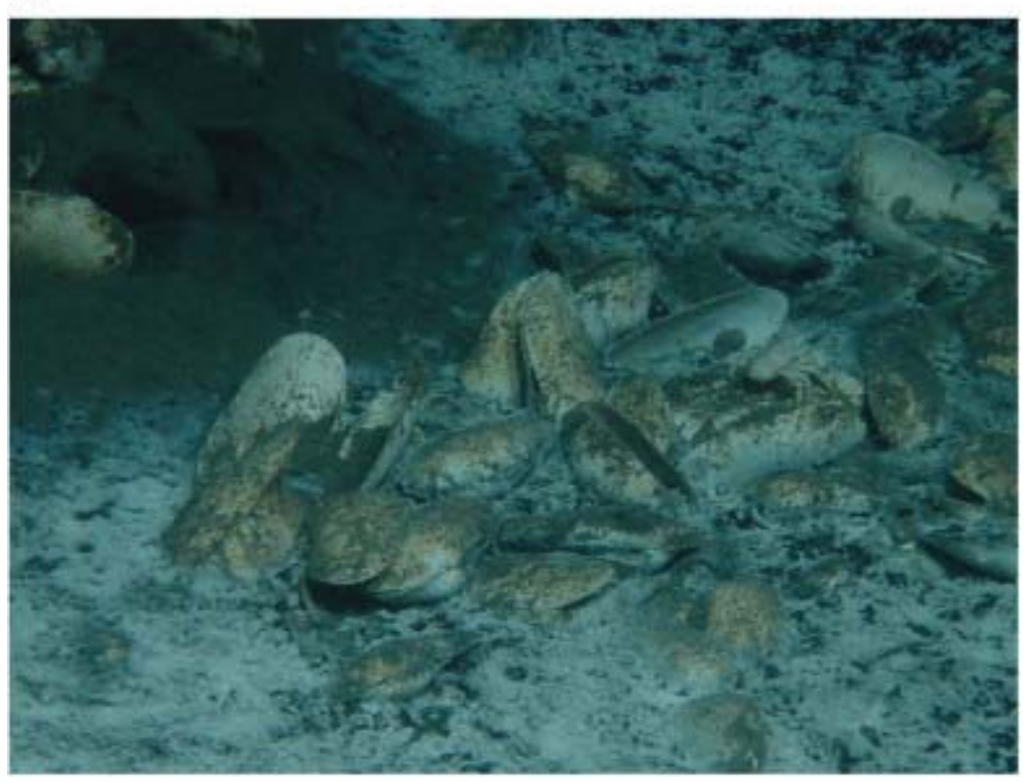

Figure 5

Sea floor pictures on a pockmark area (Regab site) obtained during the Ifremer BIOZAIRE 2 cruise with the ROV Victor 6000 on board l'Atalante: (A) Large cold seep Vesicomyidae clusters ("Calyptogena" regab n. sp., Cosel and Olu 2009; (B) bacterial mats near Vesicomyidae shells 
(A)

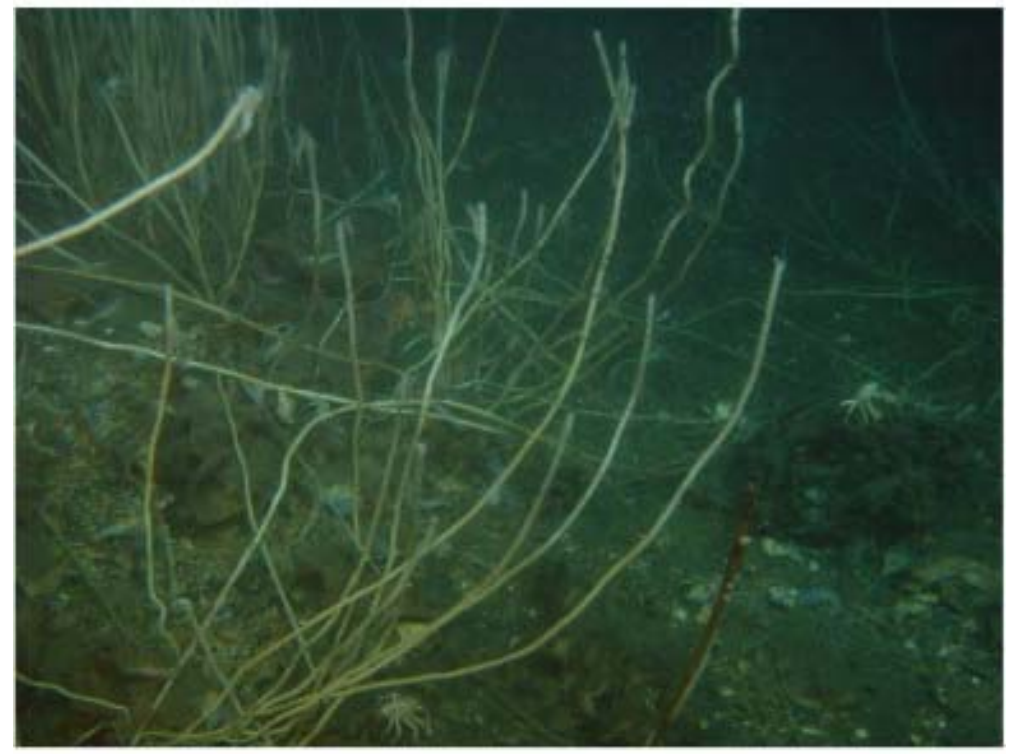

(B)

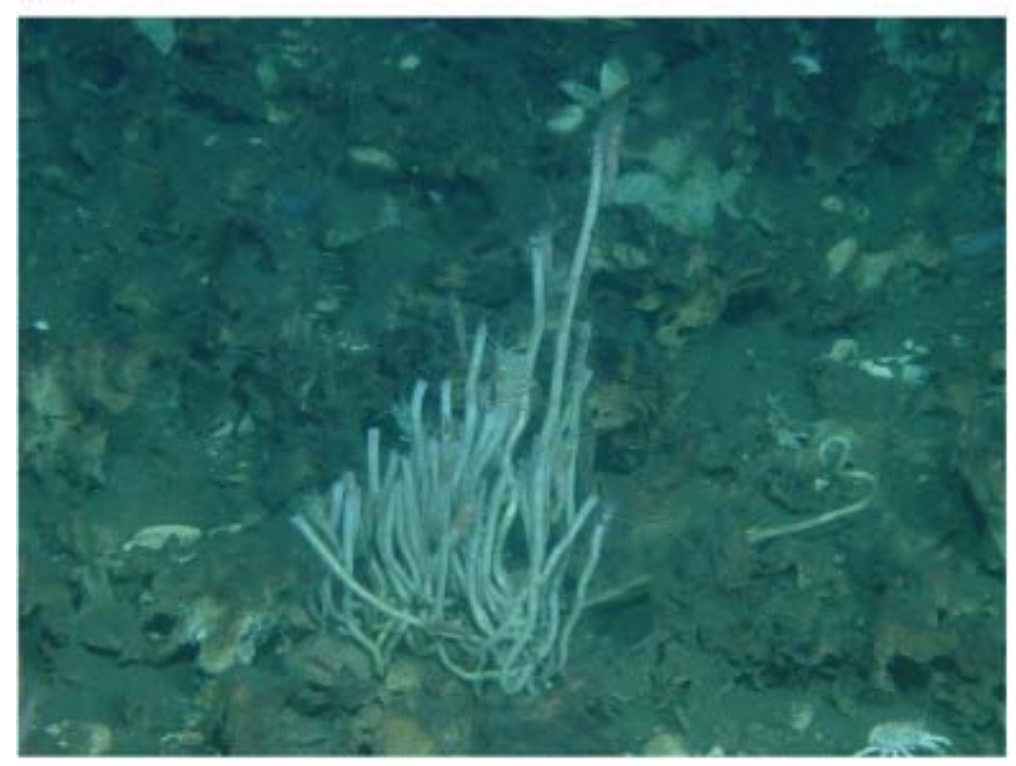

(C)

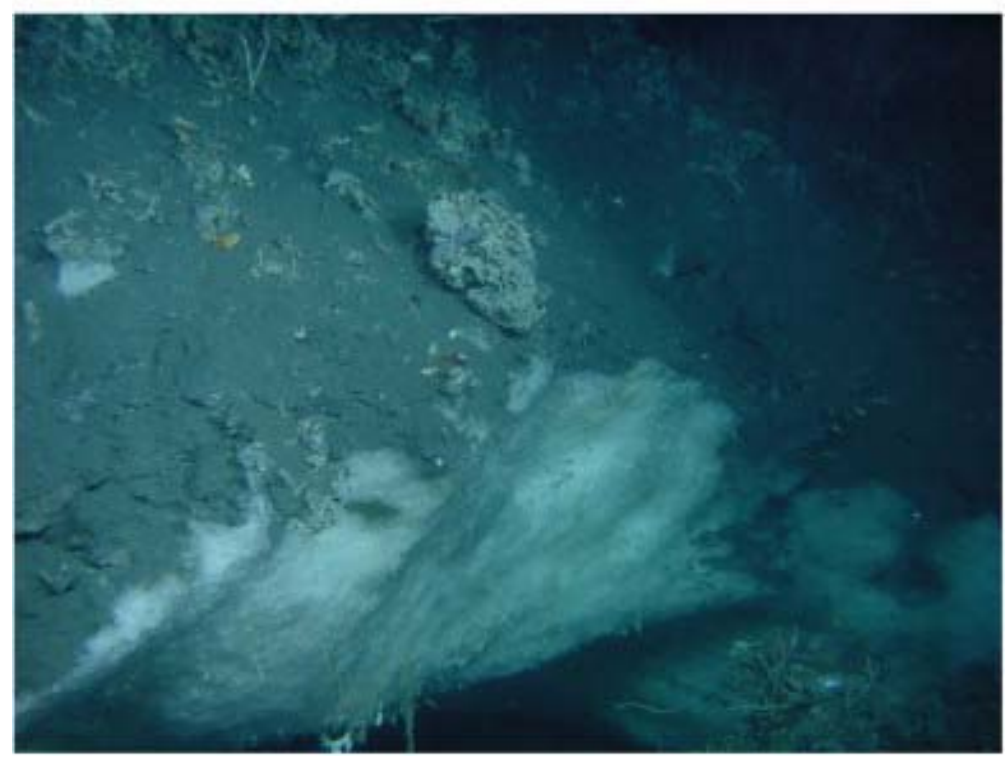


Figure 6.

Sea floor pictures on a pockmark area (Regab site) obtained during the Ifremer BIOZAIRE 2 cruise with the ROV Victor 6000 on board l'Atalante: (A) cold seep Siboglinidae Escarpia southwardae tube worms; (B) a bush of small tube worms near gas hydrate outcrop (C).

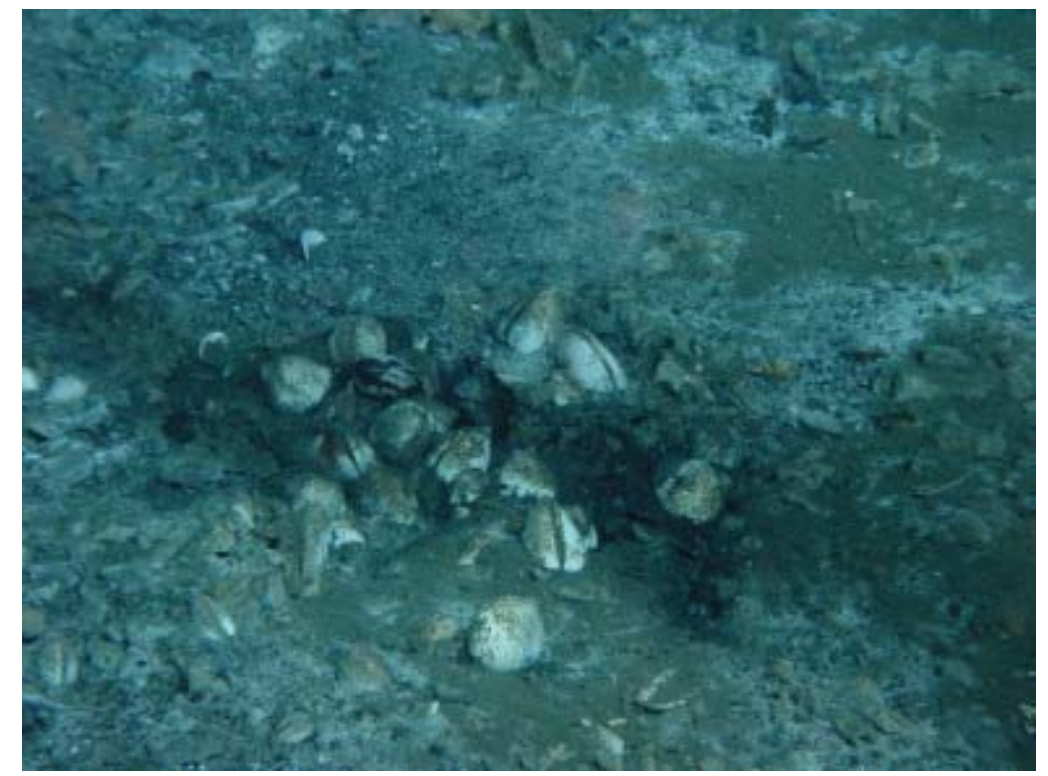

\section{Figure 7}

Sea floor pictures on a pockmark (Guiness site) obtained during the Ifremer BIOZAIRE 2 cruise with the ROV Victor 6000 on board l'Atalante: small aggregate of Vesicomyidae ( calyptogena valdiviae (Thiele \& Jaeckel, 1931) shell length: 5-7 cm) and bacterial mat. 